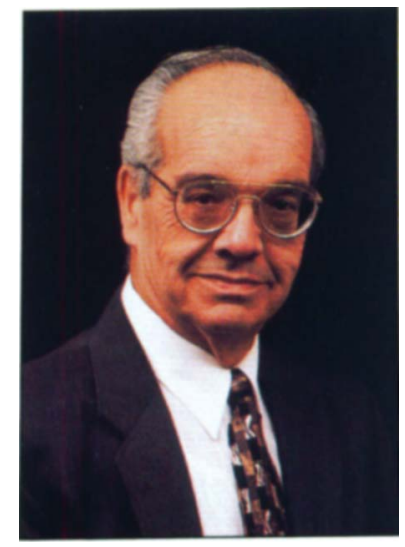

\title{
Times and programs change, but Division carries on tradition of public service
}

W.R. GOMES

Vice President

Agriculture and Natural Resources

n 1875 Eugene Hilgard, the dean of UC Berkeley's College of Agriculture, began his 30-year career as a one-man operation, visiting farms throughout the state, inviting growers to send him their questions, and answering their letters personally.

By 1900, Hilgard had guided the College, and to some extent California agriculture, through a radical transformation. The College had grown from a staff of one to 30 - some of whom helped Hilgard answer close to 15,000 letters a year. Californians had tripled in number to 1.5 million, becoming more diverse through waves of immigration.

UC agricultural scientists had significantly improved the lot of these new settlers. Hilgard himself had produced a comprehensive inventory of the state's alkali soils; he and others laid the foundations of grape-growing and winemaking, helped fight the grape-destroying phylloxera, engineered irrigation systems and launched an array of specialty crops, such as olives.

Today, as another century is about to begin, we must once again transform ourselves to meet the needs of a radically changing population. UC's Division of Agriculture and Natural Resources must now serve a diverse population of 33 million Californians. And as was true a century ago, Californians require more than research generated by land-grant university scientists; they require the University's outreach and public service.

The nation's leaders recognized this need at the turn of the century, and in 1914, President Woodrow Wilson signed the Smith-Lever Act establishing a nationwide extension service. The resulting three-way partnerships among federal, state and local governments would enable states to enlist farm advisors across the country. Advisors would take the University to the people, going out to farms to demonstrate seed selection, fertilization or pruning, and to disseminate the results of new research, applying them to local conditions.

From its beginning, the nation's extension service was mandated to improve not only production techniques, but living conditions. B.H. Crocheron, California's first extension director, urged farm advisors to strengthen the "civilizing forces of the community - youth clubs, farmers' associations, schools and churches." His goals were not only to provide local agricultural education but to "promote the social institutions of country life."

California's earliest farm advisors worked on rodent control campaigns, better-roads movements, community beautifi- cation through landscaping, hot lunch programs in rural schools, and first aid demonstrations, among other projects, according to Ann Scheuring's Science and Service. As early as 1912, farm advisors began to oversee boys' and girls' agricultural clubs in California schools, precursors of the $4-\mathrm{H}$ clubs.

Today, Cooperative Extension still addresses community needs, serving not only agriculture, but living conditions for all Californians - as illustrated by the articles in this issue.

For instance, new research in Yolo and Solano counties has demonstrated that bats are beneficial to agriculture because they feed on insects that are agricultural pests (see p. 8). With additional research to determine their roosting and foraging behavior in agricultural locations around the state, bats could play a key role in integrated pest management.

To educate farmworker families about motor vehicle safety, UC researchers designed a program called ¡Maneje Seguro! (Drive Safely!), based on the popular La Loteria game in Mexico (see p. 11). Safe-driving information was disseminated in mass media. The program was designed to increase safe driving behavior among the hundreds of thousands of San Joaquin Valley farmworkers, for whom the largest documented cause of injuries and fatalities is motor vehicle crashes.

Biological control scientists have successfully enlisted parasitic wasps in the control of a eucalyptus pest, blue gum psyllid, on the California coast (see p. 31). The insect, first reported in 1991, had spread to 12 coastal counties. It affected baby blue gum cut-foliage plantations, reducing harvest $30 \%$, or $\$ 30$ million, and requiring repeated and expensive pesticide applications. Since 1992, the cost benefits of this biological control program have been more than nine-fold (see p. 35).

Today's CE outreach (p, 4) is further illustrated by an unusual project involving 10th graders at McClymond's High in Oakland, who have created the "City Bugs" website in which they are entering information about insect specimens collected in their own neighborhoods. The project introduces the students to the principles of entomology and biological diversity, while enabling them to identify themselves as future university students and scientists.

We are doing new things for new people and audiences for the same reasons we did in the past. Our role is to reach out to the community, including those involved in production agriculture, and the many Californians who are not. In a state that is the nation's largest and one of its most ethnically diverse, we are called upon to serve all of our publics as we lay the groundwork for the 21 st century. 